\title{
Control of Algal Blooms in Eutrophic Water Using Porous Dolomite Granules
}

\author{
Jae-Hoon Huh, Young-Hoon Choi*, Shin Haeng Lee*, \\ Sun Hee Cheong**, and Ji Whan Ahn****† \\ Department of R\&D, Korea Institute of Limestone and Advanced Materials, Danyang 27003, Korea \\ *Advanced Materials and Technology Lab., Daesung Mining Development Incorporation, Yeongwol 33058, Korea \\ **Department of Marine Bio Food Science, College of Fisheries and Ocean Science, Chonnam National University, \\ Yeosu 59626, Korea \\ ***Carbon Resource Recycling Appropriate Technology Center, Korea Institute of Geoscience and Mineral Resources, \\ Daejeon 34132, Korea
}

(Received July 20, 2016; Revised January 13, 2017; Accepted February 9, 2017)

\begin{abstract}
The use of aluminum-based coagulants in water pretreatment is being carefully considered because aluminum exposure is a risk factor for the onset of Alzheimer's disease. Lightly burned-dolomite kiln dust (LB-DKD) was evaluated as an alternative coagulant because it contains high levels of the healthful minerals calcium and magnesium. An organic pore forming agent (OPFA) was incorporated to prepare porous granules after OPFA removal through a thermal decomposition process. A spray drying method was used to produce uniform and reproducible spherical granules with low density, since fine dolomite particles have irregular agglomeration behavior in the hydration reaction. The use of fine dolomite powder and different porosity granules led to a visible color change in raw algae (RA) containing water, from dark green to transparent colorlessness. Also, dolomite powders and granules exhibited a mean removal efficiency of $48.3 \%$ in total nitrogen (T-N), a gradual increase in the removal efficiency of total phosphorus (T-P) as granule porosity increased. We demonstrate that porous dolomite granules can improve the settling time and water quality in summer seasons for the emergent treatment of excessive algal blooms in eutrophic water.
\end{abstract}

Key words : Dolomite, Porous granule, Coagulant, Algal removal, Settling time

\section{Introduction}

$\mathrm{W}$ ith increasing demand for high-quality water resources around the world, water quality standards for discharging various contaminants are becoming increasingly stringent. Water pollution causes imbalances and disruptions in aquatic freshwater ecosystems and sometimes leads to the excessive growth of algae, the primary producer in this ecosystem. ${ }^{1,2)}$ Eutrophic lakes and rivers with high contents of phosphorous and nitrogen compounds have elevated levels of BOD, COD and $\mathrm{pH}$, as well as sufficient lighting and warm temperature, all of which foster excessive growth of algae.-7)

Even after a water treatment process, remaining algae residues still sometimes contain substances that threaten human health, including bacterial contaminants, pathogens, and nutrients and so on. Generally, to improve water levels to acceptable quality standards, the following four successive steps are taken: (1) coagulation (2) settling (3) filtering and (4) disinfection.

Coagulation is a process in which these suspended materi-

\footnotetext{
Corresponding author: Ji Whan Ahn

E-mail : ahnjw@kigam.re.kr

Tel : +82-42-868-3578 Fax : +82-42-861-3990
}

als are settled by gravity sedimentation, usually in reaction to ionic (or polymeric) coagulants. Algal particles that are suspended on the water surface exist in the form of anionic colloids, whose repulsive power can result in the distribution of individual cells within a certain distance. It can take several seconds to dozens of days for such dispersed $\left(>10^{-1}\right.$ $\mu \mathrm{m})$ particles to settle, whereas it takes many years to several decades for colloidal $\left(<10^{-2} \mu \mathrm{m}\right)$ particles to settle. Meanwhile, particles contained in a solution $\left(<10^{-3} \mu \mathrm{m}\right)$ do not settle at all. The use of an inorganic coagulant that has cationic Van der Waals bonds causes algal particles to come into contact with one another, which causes their volume and weight to increase, and eventually leads to a settling process by gravity. The most efficient methods to remove algae residues and contaminants, are to utilize simple yet economical materials. ${ }^{8)}$ Furthermore, the porosity, the particle size and the settling rate of these materials are crucial factors to effectively remove or move impurities or algal particles in lentic lakes and rivers, and in sewage and waste water treatment plants. ${ }^{9,10)}$

The development of an efficient coagulant with the above physical properties can consequently contribute to improving the removal efficiency of algal blooms and nutrients. Recently, it has been reported that in certain type of solid waste recycling, a large amount of $\mathrm{Ca}^{2+}$ cations dissolved 
from calcined oyster shell powder $(<100 \mu \mathrm{m})$ can be utilized to induce hydration and carbonation reactions which facilitate coagulation and the settling of nutrients and algal blooms in lakes. ${ }^{11-13)}$

Since dissolved aluminum may remain in drinking water even after a purification process, it is necessary to develop alternatives of aluminum-based coagulants. Mainly ingested via drinking water, foods, antacids, and etc., aluminum exposure above a certain concentration may cause the onset of Alzheimer's disease due to neurotoxicity. ${ }^{14,15)}$

Dolomite is well known as an attractive mineral resource containing a major source of $\mathrm{MgO}$ and $\mathrm{CaO}$. However, lightly burned-dolomite kiln dust (LB-DKD) particles smaller than $5 \mu \mathrm{m}$ are classified as a solid waste in the steel industry, and these particles are typically disposed in a landfill or used for mine recovery purposes. Recycling of LB-DKD waste resources is worth considering, both to save nonrenewable resources as well as to preserve limited landfill space. ${ }^{16,17)}$ Since zeta potential of LB-DKD is increased in the positive direction by both $\mathrm{Ca}^{2+}$ and $\mathrm{Mg}^{2+}$ cations, it is also a potential coagulant, which can react with the aforementioned anionic algal colloids. ${ }^{18)}$ Furthermore, half-burned dolomite is also known to perform very well for removing the phosphorous contained in various types of waste water, by generating amorphous phosphorus compounds. ${ }^{19)}$

LB-DKD particles are finely sieved after the grinding milling process, but the particles have a tendency to agglomerate in a dramatic density increase of uneven particle sizes to reduce high surface energy during the hydration process. Here, we introduce a new method to reduce the agglomeration of fine LB-DKD particles in which the particles are transformed into granules with a large specific surface area and low density. ${ }^{20,21)}$ Controlling the size and porosity of the LB-DKD granules led to their immediate coagulation with algal colloid particles and settling responses, producing dramatically visible changes in water transparency and light transmittance. Ultimately, the development of potential coagulant with porous LB-DKD granules can create new market as a high value-added material and also contribute to conserve water resources and aquatic ecosystems, by mitigating contaminated impurities and algal blooms through immediate responses in water treatment plants and eutrophic freshwater lakes.

\section{Experimental Procedures}

LB-DKD, calcined in a shaft kiln, was obtained from supplies left behind after iron and steel manufacturing (provider: Daesung Mining Development Incorporation). The LB-DKD particles were physically separated by sieving into four sizes: larger than $1 \mathrm{~mm}, 0.3 \sim 1 \mathrm{~mm}$, smaller than 0.3 $\mathrm{mm}$, and smaller than $0.1 \mathrm{~mm}$. X-ray fluorescence (XRF) was measured to compare difference of chemical composition and impurities with the size distributed particles. The LB-DKD particles were ground into uniformly fine particles using a wet ball mill, and were then moved into a spray

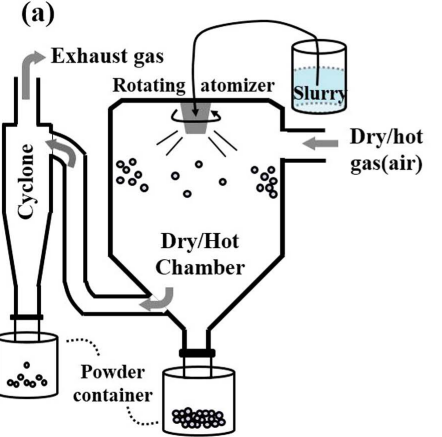

(b)

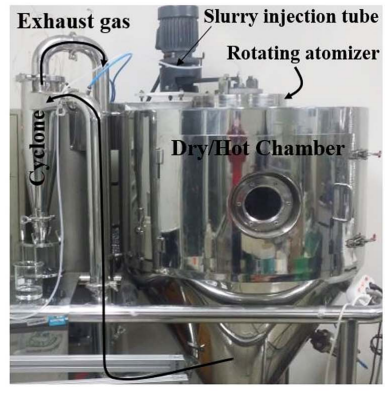

Fig. 1. Schematic illustration of the spray dryer process: (a) inner design and (b) practical equipment.

dryer chamber to be formulated into spherical granules. Stearic acid was selected to pore forming agent which has two ranges of size distribution, such as $0.1 \sim 0.43 \mathrm{~mm}$ and $0.6 \sim 1.0 \mathrm{~mm}$.

Figure 1 shows the flow diagram and process illustration corresponding to the practical spray dryer, for better understanding. A suspended LB-DKD slurry was prepared to appropriate mixed ratios of an organic pore forming agent (OPFA), binder and water. The slurry was injected into a rotating atomizer where it comes into contact with air and a gas heater. The newly created droplets are sprayed into the chamber, and then porous granules with a uniform size distribution are gathered at the bottom container of the chamber. ${ }^{22)}$ During this process, the liquid evaporates and the solid particle is calcined by a thermal treatment process at $450^{\circ} \mathrm{C}$. The fine LB-DKD particles and granules were coated with $10 \mathrm{~nm} \mathrm{Au}$ to make the surfaces conductive, and then they were examined by scanning electron microscopy (SEM, JEOL JSM-6380LA). Their size distribution was compared and analyzed using a particle size analyzer (Malvern, Mastersizer 2000). To compare the settling rates of the fine LB$\mathrm{DKD}$ particle and granules in deionized water of equivalent volumes and heights, samples were scattered on the water's surface and the settling process was simultaneously recorded on video. Optical photographs of each sample were captured from the side view after 5 minutes, and top view after 30 minutes, and were used to compare the amount of residually floating particles.

Raw algae (RA) containing water, collected in October 2015 from Daecheong Lake (36 $\left.20^{\prime} 59.3^{\prime \prime} \mathrm{N} 127^{\circ} 33^{\prime} 31.4^{\prime \prime} \mathrm{E}\right)$, the third largest artificial lake in Korea, was then used to observe coagulant performance of the fine LB-DKD particle and granules. Fine LB-DKD particles and granules with various specific surface areas were added to the RA containing water, and water transparency and light transmittance changed by their coagulation performance were visibly observed. Measurement of the water quality (Auto Analyzer 3 ((AA3)-HR)) was carried out to determine the increase in the ratio of transformed nutrients, and the efficiency of nutrient removal in RA containing water. Table 1 lists the measured wavelengths $(\mathrm{nm})$ and concentrations $(\mathrm{mg} / \mathrm{L})$ of the standard solutions, corresponding to the total nitrogen 
Table 1. Specific Wavelength and Different Concentrations of Standard Solution, with Analysis of Nutrient Salts

\begin{tabular}{ccc}
\hline Nutrient & Wavelength $(\mathrm{nm})$ & Standard solution $(\mathrm{mg} / \mathrm{L})$ \\
\hline $\mathrm{T}-\mathrm{N}$ & 550 & $10,5.0,2.5$ \\
$\mathrm{~T}-\mathrm{P}$ & 800 & $1.0,0.5,0.25$ \\
$\mathrm{NO}_{3}-\mathrm{N}$ & 550 & $1.0,0.5,0.25$ \\
$\mathrm{NO}_{2}-\mathrm{N}$ & 550 & $0.2,0.1,0.05$ \\
$\mathrm{PO}_{4}-\mathrm{P}$ & 800 & $0.5,0.25,0.125$ \\
$\mathrm{NH}_{4}-\mathrm{N}$ & 630 & $1.0,0.5,0.25$ \\
\hline
\end{tabular}

(T-N), and total phosphorus (T-P) of various nutrients $\left(\mathrm{NO}_{2}\right.$, $\mathrm{NO}_{3}, \mathrm{PO}_{4}$ and $\mathrm{NH}_{4}$ ).

\section{Results and Discussion}

Figure 2 shows optical photographs of the calcined LBDKD particles which were separated by physically sieving into three sizes: larger than $1 \mathrm{~mm}, 0.3 \sim 1 \mathrm{~mm}$, smaller than $0.3 \mathrm{~mm}$, and smaller than $0.1 \mathrm{~mm}$. Table 2 shows the chemical compositions of the LB-DKD particles within a specific range of size distribution. The composition ratios of $\mathrm{CaO}$
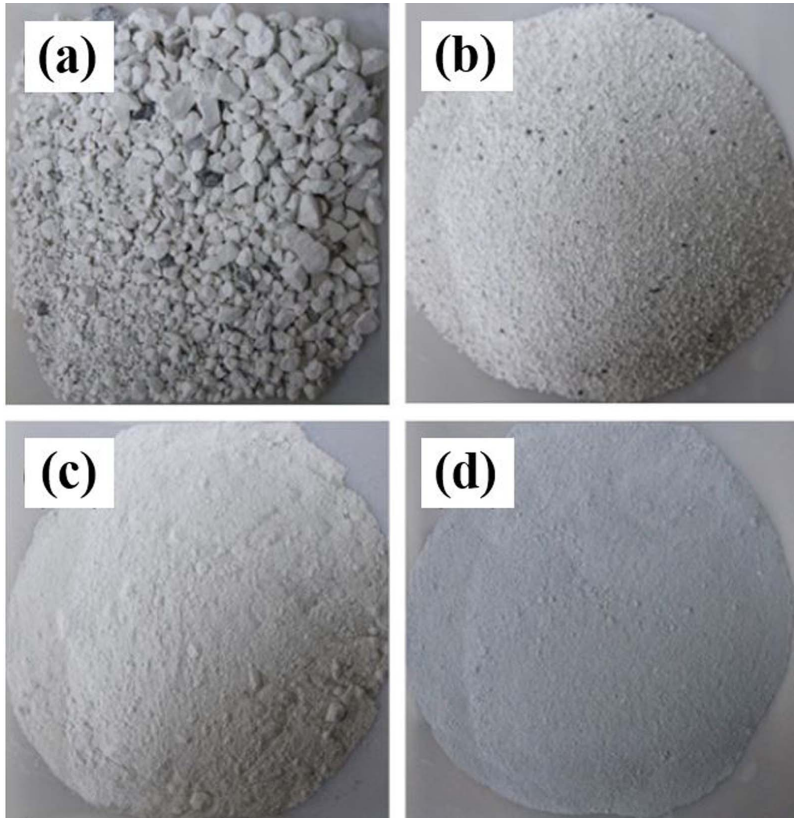

Fig. 2. Optical images of the LB-DKD samples with size distribution after particle separation using sieve trays: (a) $>1 \mathrm{~mm}$, (b) $0.3 \sim 1 \mathrm{~mm}$, (c) $<0.3 \mathrm{~mm}$ and (d) $<0.1 \mathrm{~mm}$ $(\sim 49 \%)$ and $\mathrm{MgO}(\sim 33 \%)$ reached to $\sim 82 \%$, since the $\mathrm{CaO}$ content was more than 1.5 times that of the MgO.

Even though the residual minerals remained after the water treatment, $\mathrm{Mg}$ has a beneficial role in over 300 enzymatic reactions with human cells, and $\mathrm{Ca}$ is also an essential element in the human body for building strong bones, teeth and blood. ${ }^{23)}$ Additional impurities, accounting for 3\% of the total, include metal and nonmetallic oxides of $\mathrm{Al}$ $(<0.5 \%) \mathrm{Fe}, \mathrm{Na}$, and $\mathrm{Si}$, as well as coal ash by-product, with $\mathrm{C}, \mathrm{CO}_{2}$ and moisture. These results indicate that the chemical composition of the LB-DKD particles is not dependent on the size distribution process such as physical sieving and ball milling.

Figure 3 shows the surface morphology and size distribution of the agglomerating LB-DKD particles after the wet ball milling process and three various porous granules via the spray dryer process. The LB-DKD particles in Fig. 3(a) exhibit a broad size distribution, with two high peaks at 3 $\mu \mathrm{m}$ and $25 \mu \mathrm{m}$ with high-density agglomerating tendencies, up to $100 \mu \mathrm{m}$. Here, we found that the addition of stearic acid with different size distribution, such as $0.1 \sim 0.43 \mathrm{~mm}$ and 0.6 1.0 mm as shown in Table 3, was a crucial factor in controlling surface roughness, and in generating organic pores in the granules.

Figure 3(b) shows the surface morphology and size distribution of the granules when stearic acid was not added, as shown in Table 3(a). Because the fine LB-DKD powders are tightly connected with each other, they appear to be a spherical granules with an average size distribution of 52 $\mu \mathrm{m}$, with small surface roughness and pores. Fig. 3(c) shows a spherical granule with an average size distribution of 58 $\mu \mathrm{m}$ with medium surface roughness and partially enlarged pores. Fig. 3(d) shows a spherical granule with an average size distribution of $60 \mu \mathrm{m}$ with large surface roughness and many enlarged pores. These three types of granules have a relatively uniform size distribution of between 50 to $60 \mu \mathrm{m}$ regardless of their different porosities. These functional similarities are sufficient to allow a comparison of their coagulation performance with algal blooms depending on differences in porosity.

Figure 4 shows the settling behaviors of the LB-DKD particle and granules with different porosities. Top view and side view images of the particles and granules after 5 minutes and 30 minutes were used to estimate the amount of residually floating particles. A lot of LB-DKD particles remained floating on the water surface, and suspended in the water column, even after 30 minutes reflecting random

Table 2. X-ray Fluorescence (XRF) Results of Lightly Burned-Dolomite Kiln Dust (LB-DKD) Samples after Size-Distributed Particle Separation Using Sieve Trays: (a) $>1 \mathrm{~mm}$, (b) $0.3 \sim 1 \mathrm{~mm}$ and (c) $<0.3 \mathrm{~mm}$ (unit: \%)

\begin{tabular}{|c|c|c|c|c|c|c|c|c|}
\hline \multirow{2}{*}{ Particle size } & \multicolumn{8}{|c|}{ Chemical Composition } \\
\hline & $\mathrm{CaO}$ & $\mathrm{MgO}$ & $\mathrm{SiO}_{2}$ & $\mathrm{Al}_{2} \mathrm{O}_{3}$ & $\mathrm{Fe}_{2} \mathrm{O}_{3}$ & $\mathrm{Na}_{2} \mathrm{O}$ & $\mathrm{CaO} / \mathrm{MgO}$ & Igloss \\
\hline (a) $>1 \mathrm{~mm}$ & 49.34 & 33.11 & 1.39 & 0.41 & 0.49 & 0.22 & 1.49 & 15.27 \\
\hline (c) $<0.3 \mathrm{~mm}$ & 49.54 & 33.23 & 1.70 & 0.54 & 0.48 & 0.25 & 1.49 & 14.23 \\
\hline
\end{tabular}



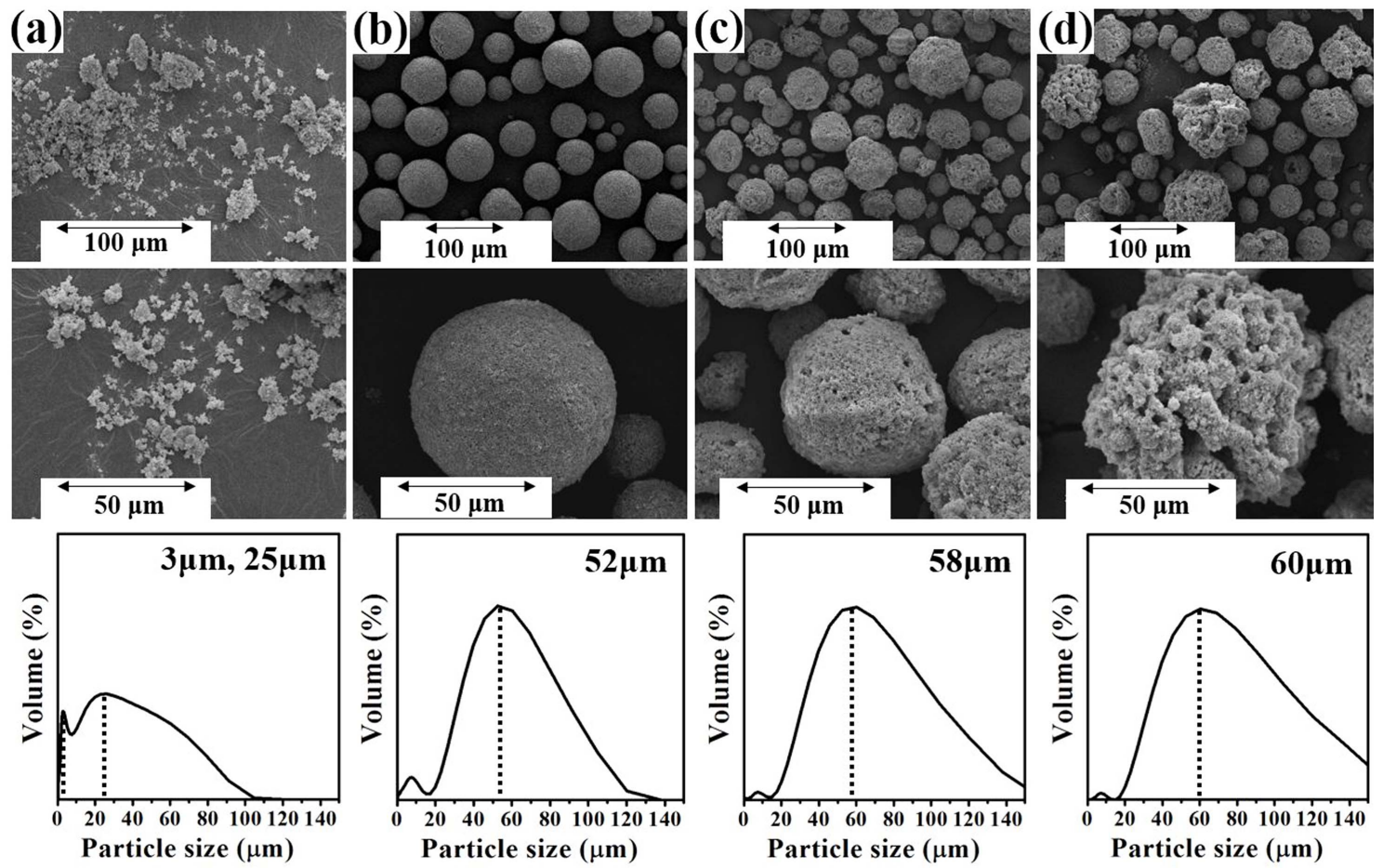

Fig. 3. SEM images of LB-DKD and granules with different specific surface areas and size distribution: (a) 3 and $25 \mu \mathrm{m}$, (b) 52 $\mu \mathrm{m}$, (c) $58 \mu \mathrm{m}$ and (d) $60 \mu \mathrm{m}$.

Table 3. Slurry Composition in Terms of the Respective Weights of the LB-DKD Particles, Binder, Organic Pore-Forming Agent (Stearic acid, SA) and Water for Preparation of Porous Dolomite Granules by Spray Dryer Method

\begin{tabular}{ccccc}
\hline Sample & DKD & PFA & Binder & Water \\
\hline (a) & $100 \mathrm{~g}$ & $0 \mathrm{~g}$ & $0.25 \mathrm{~g}$ & $450 \mathrm{~g}$ \\
(b) & $100 \mathrm{~g}$ & SA $0.1 \sim 0.43 \mathrm{~mm}, 9 \mathrm{~g}$ & $0.25 \mathrm{~g}$ & $450 \mathrm{~g}$ \\
(c) & $100 \mathrm{~g}$ & SA $0.6 \sim 1.0 \mathrm{~mm}, 9 \mathrm{~g}$ & $0.25 \mathrm{~g}$ & $450 \mathrm{~g}$ \\
\hline
\end{tabular}

settling behaviors for the irregularly aggregated size distribution.

The relatively large granules with different surface areas, on the contrary, sank to the bottom due to their fast settling rate and then some of them became suspended and repeatedly settled down to the bottom again, due to the low height of water column. The transparency differences of the surface layer, middle layer and the bottom layers in the water (a)

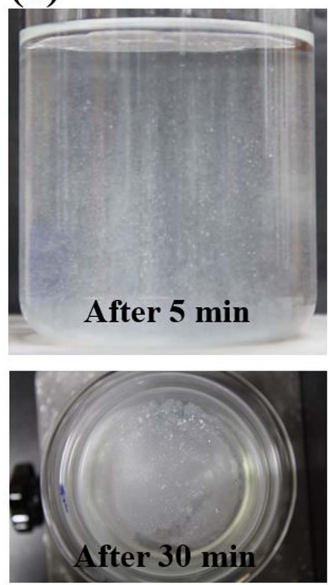

(b)
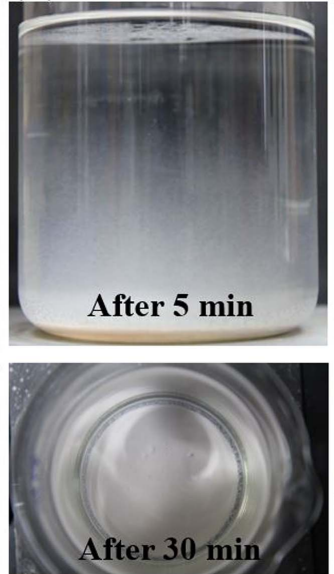

(c)
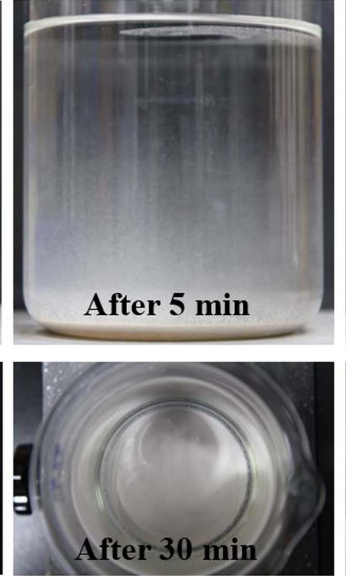

(d)
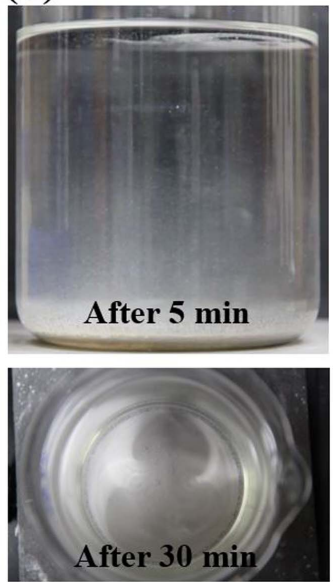

Fig. 4. Side and top views illustrating visual differences in settle time of LB-DKD particles and granules after 5 or 30 min in water media: (a) 3 and $25 \mu \mathrm{m}$ LB-DKD, (b) $52 \mu \mathrm{m} \mathrm{SG}$, (c) $58 \mu \mathrm{m} \mathrm{MG}$ and (d) $60 \mu \mathrm{m} \mathrm{LG}$. 

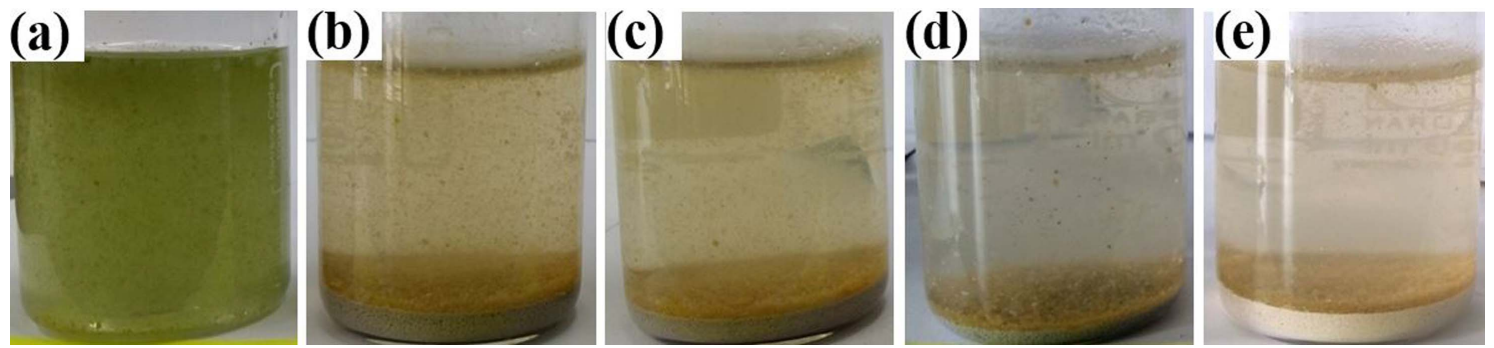

Fig. 5. Optical images of algae removal performance of coagulants with different specific surface areas and size distribution: (a) raw algae (RA) containing water, (b) LB-DKD, (c) $52 \mu \mathrm{m} \mathrm{SG}$, (d) $58 \mu \mathrm{m} \mathrm{MG}$ and (e) $60 \mu \mathrm{m} \mathrm{LG}$.

column confirmed that the granules with uniform size had a better settling rate than the LB-DKD particles, while the various surface areas of the granules led to minor differences in their suspended behavior. No floating particles could be seen on the water surface after 30 minutes of the experiment, since most of the granules showed remarkable bottom sedimentation.

Figure 5 shows visible performance changes in the coagulation process of the LB-DKD particles and the granules in RA containing water from Daecheong Lake. Regardless of their physical properties, or the aggregation, shape and pore size of the LB-DKD particle and the granules, their addition to the green RA containing water dramatically changed it to a transparent color, due to their algae coagula-
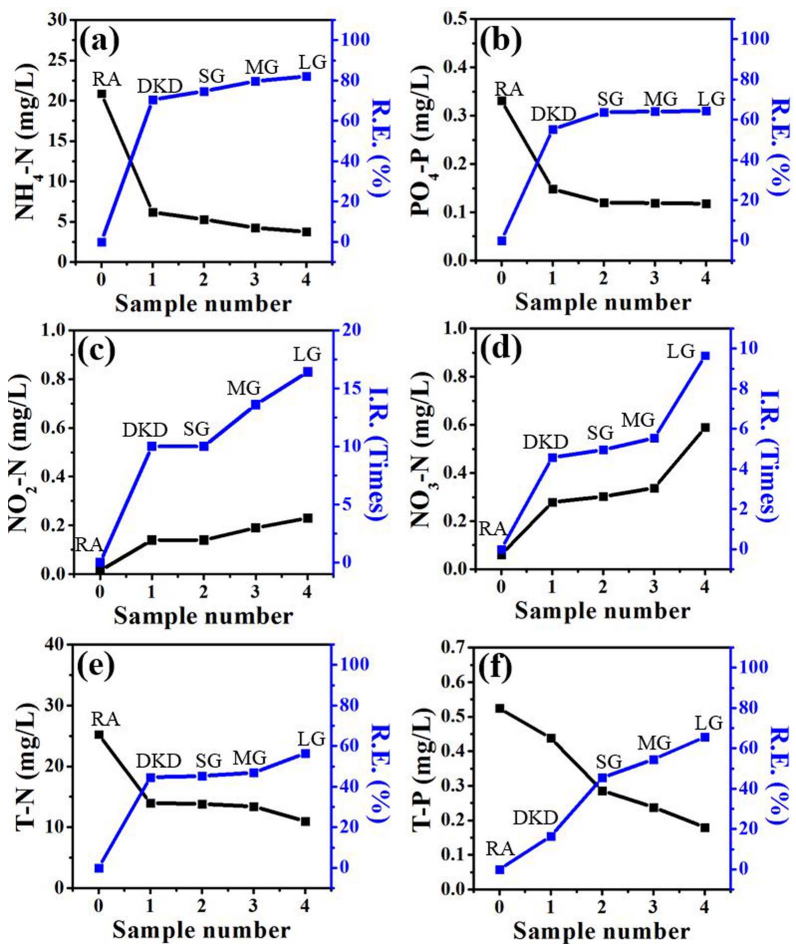

Fig. 6. Increase ratio (I.R.) and removal efficiency (R.E.) of various nutrient salts by coagulation process of dolomite kiln dust (DKD), small porosity granule (SG), medium porosity granule (MG) and large porosity granule (LG), compared to RA containing water: (a) $\mathrm{NH}_{3}-\mathrm{N}$, (b) $\mathrm{PO}_{4}-\mathrm{P}$, (c) $\mathrm{NO}_{2}-\mathrm{N}$, (d) $\mathrm{NO}_{3}-\mathrm{N}$, (e)T-N and (f) T-P. tion and sedimentation performance. In particular, the larger surface area and lower density behavior of the granules as compared with the LB-DKD particles, gradually contributed to the reduction of the suspended algal cells as a result of the more active coagulation and sedimentation performance. The effectiveness of the LB-DKD particles and granules is useful for not only the abovementioned four step water treatment plant process, but can be practically used for lentic lakes and rivers with summer algal blooms. Furthermore, the DKD particles and granules consisting of beneficial $\mathrm{Mg}$ and $\mathrm{Ca}$ components are expected to be a potential replacement for aluminum-based coagulants.

Figure 6 shows the removal efficiency of $\mathrm{NH}_{3}-\mathrm{N}, \mathrm{PO}_{4}-\mathrm{P}, \mathrm{T}$ $\mathrm{N}$, and T-P and the increased ratio of $\mathrm{NO}_{2}-\mathrm{N}, \mathrm{NO}_{3}-\mathrm{N}$ based on the coagulation performance of the LB-DKD particles (DKD), low-porosity granules (SG), medium-porosity granules (MG), and large-porosity granules (LG) in water containing RA. The level of nutrients $\left(\mathrm{NH}_{3}-\mathrm{N}, \mathrm{PO}_{4}-\mathrm{P}, \mathrm{T}-\mathrm{N}\right.$, and $\mathrm{T}-\mathrm{P}$ ) in the RA containing water indicated a higher removal efficiency for the high porosity granules rather than for the low porosity granules and for the granules rather than the fine particles, respectively. The $\mathrm{NH}_{3}-\mathrm{N}$ converts to two nitrogen oxide forms, which corresponds to a first conversion from $\mathrm{NH}_{3}$ to $\mathrm{NO}^{2-}$ and then a consecutive conversion of $\mathrm{NO}^{2-}\left(\mathrm{NO}_{2}-\mathrm{N}\right)$ to $\mathrm{NO}^{3-}\left(\mathrm{NO}_{3}-\mathrm{N}\right)$ by a two-step nitrification process. With addition of DKD particle and granules, the removal efficiency of T-N and $\mathrm{PO}_{4}-\mathrm{P}$ showed similar levels, of $45-60 \%$ and $55-65 \%$, respectively, while the removal efficiency of T-P gradually increased to order of DKD particles, low porosity granules and higher porosity granules. T$P$ removal efficiency was most dependent on size uniformity and porosity, since the efficiency of the high porosity granules was more than $50 \%$ greater than that of the DKD particles.

\section{Conclusions}

LB-DKD particles, consisting of a uniform content of $\mathrm{Mg}$ and $\mathrm{Ca}$ of beneficial elements to the human body, were used as mineral resource for coagulation of algal blooms in practical water resources and water treatment plants. Low-density LB-DKD granules with various porous surface area and almost 50 - $60 \mu \mathrm{m}$ size distribution were prepared to enhance individual particle fluidity and to improve the agglomera- 
tion behavior of fine LB-DKD particles after wet ball milling. When the particles and granules were added to a water column, the resulting differences over time in the transparency of the respective water surface layers, middle layers and the bottom layers indicated that the granules with uniform size had a better settling rate than the particles of nonuniform size. We demonstrated that the addition of the LBDKD particles and the granules to RA containing water led to water quality improvement, indicated by color change and reduction of suspended algal cells due to their algae coagulation and sedimentation performance. The conversion rate of $\mathrm{NH}_{3}-\mathrm{N}(\sim 80 \%)$ by a two-step nitrification process indicated particularly excellent efficiency. The removal efficiency of T-N, T-P and $\mathrm{PO}_{4}-\mathrm{P}$ also showed remarkable improvement with the addition of the LB-DKD particles and granules. These results demonstrate that the use of coagulants based on the LB-DKD particles and granules is the cheapest, fastest and most environmentally friendly working method toward sustainable freshwater development, in addition to being a potential replacement of aluminum-based coagulants.

\section{Acknowledgments}

The authors deeply appreciate the financial support from the Korea Institute of Energy Technology Evaluation and Planning (KETEP) through the ETI program, Ministry of Trade, Industry and Energy (MOTIE, Project No. 2013T100100021) and from the Algae Research and Development Project of Danyang-gun, Chungcheongbuk-do through the Korean Local Autonomous Entity. This work was also carried out with the support of the Cooperative Research Program for Agriculture Science \& Technology Development (Project No. PJ010181042016) through the Rural Development Administration, Republic of Korea.

\section{REFERENCES}

1. A. K.-Y. Lam, E. E. Prepas, D. Spink, and S. E. Hrudey, "Chemical Control of Hepatotoxic Phytoplankton Blooms: Implications for Human Health," Wat. Res., 29 [8] 1845-54 (1995).

2. B. Sen, M. T. Alp, F. Sonmez, M. A. T. Kocer, and O. Canpolat, "Relationship of Algae to Water Pollution and Waste Water Treatment," pp. 335-54, Chapter 14, Intech, Turkey, 2013.

3. G. P. Robertson and P. M. Groffman, "Nitrogen Transformation," pp. 341-64 in Soil Microbiology, Biochemistry, and Ecology. Springer, New York, 2007.

4. C. S. Snyder, T. W. Bruulsema, T. L. Jensen, and P. E. Fixen, "Review of Greenhouse Gas Emissions from Crop Production Systems and Fertilizer Management Effects," Agric., Ecosyst. Environ., 133 [3] 247-66 (2009).

5. V. H. Smith, G. D. Tilman, and J. C. Nekola, "Eutrophication: Impacts of Excess Nutrient Inputs on Freshwater, Marine, and Terrestrial Ecosystems," Environ. Pollut., 100 [1] 179-96 (1999).
6. V. H. Smith and D. W. Schindler, "Eutrophication Science: Where Do We Go from Here?," Trends in Ecology \& Evolution, 24 [4] 201-7 (2009).

7. D. J. Conley, H. W. Paerl, R. W. Howarth, D. F. Boesch, S. P. Seitzinger, K. E. Havens, C. Lancelot, and G. E. Likens, "Controlling Eutrophication: Nitrogen and Phosphorus," Science, 323 [5917] 1014-15 (2009).

8. J.-H. Huh and J.-W. Ahn, "A Perspective of Chemical Treatment for Cyanobacteria Control toward Sustainable Freshwater Development," Environ. Eng. Res., 22 [1] 1-11 (2017).

9. B. Ghernaout, D. Ghernaout, and A. Saiba, "Algae and Cyanotoxins Removal by Coagulation/Flocculation: A Review," Desalin. Water Treat., 20 [1-3] 133-43 (2010).

10. J. Bratby, Coagulation and Flocculation in Water and Wastewater Treatment; pp. 50-68, IWA Publishing, London, 2006.

11. J.-H. Huh, Y.-H. Choi, and J. W. Ahn, "Limestone Particles for Algae Treatment (in Korean)," Ceramist, 18 [3] 5-13 (2015).

12. J.-H. Huh, Y.-H. Choi, H.-J. Lee, W. J. Choi, C. Ramakrishna, H.-W. Lee, S.-H. Lee, and J.-W. Ahn, "The Use of Oyster Powders for Water Quality Improvement of Lakes by Algal Blooms Removal," J. Korean Ceram. Soc., 53 [1] 1-6 (2016).

13. J.-H. Huh, Y.-H. Choi, C. Ramakrishna, S. H. Cheong, and J.-W. Ahn, "Use of Calcined Oyster Shell Powder as a $\mathrm{CO}_{2}$ Adsorbent in Algae-Containing Water," J. Korean Ceram. Soc., 53 [4] 429-34 (2016).

14. P. Niquette, F. Monette, A. Azzouz, and R. Hausler, "Impacts of Substituting Aluminum-Based Coagulants in Drinking Water Treatment," Water Qual. Res. J. Can., 39 [3] 303-10 (2004).

15. L. Tomljenovic, "Aluminum and Alzheimer's Disease: After a Century of Controversy, Is there a Plausible Link?," J. Alzheimer's Dis., 23 [4] 567-98 (2011).

16. Y. Lan, Q. Liu, G. Wu, J. Yang, M. Xu, W. Ao, and Q. Chen, "Recycling of Burned Dolomite Powder in Steelmaking," Metallurgist, 57 [9-10] 862-68 (2014).

17. C. J. Lewis and B. B. Crocker, "The Lime Industry's Problem of Airborne," J. Air Pollut. Control Assoc., 19 [1] 31-9 (2012).

18. A. Kasha, H. Al-Hashim, W. Abdallah, R. Taherian, and B. Sauerer, "Effect of $\mathrm{Ca}^{2+}, \mathrm{Mg}^{2+}$, and $\mathrm{SO}_{4}{ }^{2-}$ Ions on the Zeta Potential of Calcite and Dolomite Particles Aged with Stearic Acid," Colloids Surf., A, 482 290-99 (2015).

19. H. Roques, L. Nugroho-Jeudy, and A. Lebugle, "Phosphorus Removal from Wastewater by Half-Burned Dolomite," Water Res. 25 [8] 959-65 (1991).

20. A. Santomaso, P. Lazzaro, and P. Canu, "Powder Flowability and Density Ratios: The Impact of Granules Packing," Chem. Eng. Sci., 58 [13] 2857-74 (2003).

21. H. Lu, Q. Ji, S. Ding, and P. Zheng, "The Morphological and Settling Properties of ANAMMOX Granular Sludge in High-Rate Reactors," Bioresour. Technol., 143 592-97 (2013).

22. Y.-H. Choi, J.-H. Huh, S.-H. Lee, C. Han, and J.-W Ahn, "Preparation of Spherical Granules of Dolomite Kiln Dust as Gas Adsorbent," J. Korean Ceram. Soc., 53 [1] 13-7 (2016).

23. A. Azoulay, "Comparison of the Mineral Content of Tap Water and Bottled Waters," J. Gen. Intern. Med., 16 [3] 168-75 (2001). 